\title{
Cytochemistry in the bioassay of hormones
}

\author{
J CHAYEN, LUCILLE BITENSKY
}

From the Division of Cellular Biology, Kennedy Institute of Rheumatology, Bute Gardens, London

For many pathologists, only pedantry can resolve the difference between the terms "histochemistry" and "cytochemistry". Moreover, the better known subject of histochemistry is not distinguished for its quantification. So it may come as some surprise, that the most sensitive bioassays, of polypeptide hormones, that are currently available and that are about one thousand times as sensitive as the equivalent radioimmunoassays, depend on the quantitative cytochemical measurement of the biochemical changes induced by these hormones in their targetcells. Consequently, we will review (i) how this has come about, that is, how cytochemistry has developed as a rigorous form of cellular biochemistry; (ii) how it has led to the formulation of the highly sensitive cytochemical bioassays of polypeptide hormones and of the biological effects of certain types of immunoglobulins; and (iii) how cytochemistry may possibly be applied in clinical pathology to study the biochemical changes induced by disease processes.

\section{Development of cytochemistry}

\section{BACKGROUND}

The aim of cytochemistry is the analysis of the biochemistry, including the physico-chemistry, of individual cells, whether these occur within a complex tissue; or as separate cells, as in the blood, or after isolation from a tissue, as may occur in cytological preparations for screening, or after enzymatic and mechanical disruption of a tissue, or in cell-culture procedures. Thus, essentially, cytochemistry should be a rigorous form of cellular biochemistry, an extension of biochemistry (and, therefore, of clinical biochemistry) down to the level of the individual cell.

\section{Need to relate biochemical activity to histology}

A major incentive for the development of a truly cellular biochemistry has been the fact, well known to histopathologists, that few (if any) tissues consist of a single, homogeneous population of cells. The

\section{Accepted for publication 15 October 1980}

metabolic activity of each sub-population may be characteristic, and significantly different from the mean activity of the whole population. Thus if one considers liver to consist of a single population of hepatocytes (apart from connective tissue, bile ducts, and reticuloendothelial cells), the peculiarly centrilobular necrosis induced by certain xenobiotics can be difficult to explain. ${ }^{1}$ To put the problem more generally: if the target-cells for a biologically active material (or a disease-process) constitute only $10 \%$ of the cellular population of a tissue, all having identical activities, then even a $50 \%$ increase or a $50 \%$ decrease of a metabolic process in these target-cells will constitute a change of only $\pm 5 \%$ in the total activity of the sample. This change, measured per gramme of tissue, may not be significant against normal experimental variations, whereas the change in the individual target-cells should be highly significant.

\section{Development of microdensitometry}

To achieve the sensitivity of measurement required for assaying biochemical activities, or molecules of biological importance, in individual cells, recourse was made to biophysical techniques. ${ }^{2}$ In particular, Caspersson $^{3-5}$ developed ultraviolet microspectrophotometry, in which a conventional spectrophotometer was built around a microscope, so that the biological cell, suitably magnified, replaced the cuvette of conventional spectrophotometers, and the optical signal was amplified electronically. ${ }^{6}$ Thus he used the natural absorption of nucleic acids (around $260 \mathrm{~nm}$ ) to measure the amount of these substances present in, for example, normal and malignant cells. Fundamentally the same principles could be used for measuring the amount of an artificial chromophore developed inside individual cells as a consequence of a chromogenic biochemical reaction for measuring metabolic activity, or the number of reactive chemical groups. Such measurements would be meaningful provided two criteria were met: firstly that the amount of the chromophore produced by such reactions was stoichiometric with the metabolic activity (or reactive groups), and secondly, that the chromophore did not diffuse from the site at which 
it was formed, so becoming lost to measurement. The second criterion was met by precipitating the coloured reaction-product as it formed. But this involved a new, and major, optical problem, namely the measurement of an optically inhomogeneous chromophore that might have relatively high extinction (or absorbance) values. This difficulty was overcome by the development of scanning and integrating microspectrophotometry, or microdensitometry $;^{7}$ how this procedure overcomes this potential "inhomogeneity error" has been discussed fully recently. ${ }^{6} 8$

\section{Cytochemistry of tissue sections}

The availability of commercial scanning and integrating microdensitometers, and of many apparently stoichiometric chromogenic reactions, with insoluble coloured reaction-products, for many active groups and many enzymatic activities ${ }^{9}$ should have opened the way to the prosecution of cellular biochemistry. But while these quantitative methods could readily be applied to isolated cells, as was done in the later haematological studies of Stuart and Simpson, ${ }^{10}$ Stuart, ${ }^{11}$ and Wickramasinghe, ${ }^{12}$ there were many obstacles to their application to cells in sections. These will now be considered, in relation to the way cytochemical procedures are now done on tissue sections.

\section{CHILLING AND SECTIONING}

\section{Problems}

In earlier biochemical studies it was common to use relatively thick tissue slices. These were too thick to allow detailed histological examination. Yet to cut thinner tissue slices it was necessary to harden the tissue either by embedding it in some hard matrix, like paraffin wax, or by cooling it. The first expedient was not permissible because it involved chemical fixation, with the variable but marked amounts of inhibition of enzymatic activity, or change in chemically active groups, that such procedures entail. ${ }^{9}$ The alternative was to cool the tissue until it became so hard that it could be sectioned in a cryostat. The cryostat microtome had been developed by Linderstrøm-Lang and Mogensen, ${ }^{13}$ at the Carlsberg laboratories in Copenhagen, for rigorous micro-chemical studies. However, this procedure was also fraught with problems: firstly, considerable physicochemical disruption was likely to be caused by freezing tissue; then at least part of the tissue would thaw as a result of the heat produced by the act of sectioning; and finally the section, and some of the tissue, would freeze again in the cold cryostat cabinet.
These problems have been overcome by the $\frac{\stackrel{0}{*}}{\vec{*}}$ finding ${ }^{14}$ that small blocks of tissue $\left(\mathrm{eg}, 5 \mathrm{~mm}^{3}\right)$ can $\frac{\mathrm{O}}{-}$ be chilled sufficiently rapidly as to supercool the tissue water, with no apparent crystallisation of ice. $\stackrel{\stackrel{P}{+}}{+}$ The requirements for the coolant are firstly, that it? should make good thermal contact with the tissue- 음. that is, it should remain liquid and have good thermal $\frac{\infty}{\widetilde{\sigma}}$ conductivity; and secondly, that it should note vaporise when warmed by the warm tissue. Thuses liquid nitrogen at $-190^{\circ} \mathrm{C}$ is a poor coolant because, $\vec{\circ}$ although it is liquid, it is close to its boiling point sothat it vaporises and sets up an insulating layer of $\vec{\omega}$ gaseous nitrogen around the tissue.

\section{Procedure}

Consequently, small blocks of tissue (about $5 \times 5 \circ$ $\times 3 \mathrm{~mm}$ ) are chilled by precipitate immersion in $n$-hexane at $-70^{\circ} \mathrm{C}$. The hexane is freely liquid at this temperature; its boiling range is $+67-70^{\circ} \mathrm{C}$. Thermocouple traces ${ }^{9}$ and several indirect tests ${ }^{15-}$ have failed to show any evidence of the crystallisation $\bar{c}$ of ice in such specimens.

The chilled tissue is stored in dry glass tubes at $\vec{c}$ $-70^{\circ} \mathrm{C}$. It is sectioned, eg, at $10 \mu \mathrm{m}$, in a cryostat ${ }^{\circ}$ with the cabinet temperature below $-25^{\circ} \mathrm{C}$ (below the last major triple-point, for ice-water-ice, ato $\left.-22^{\circ} \mathrm{C}\right) \cdot{ }^{16}$ The haft of the knife is cooled with solid carbon dioxide so that the heat of sectioning is dissipated into the colder, better conducting knife rather than into the tissue. The section is then "flash-dried" on to a glass slide. This is achieved흘 very simply by bringing a glass slide, from the ${ }^{\Im}$ temperature that is ambient in the laboratory $\left(\mathrm{eg},+20^{\circ} \mathrm{C}\right)$ up to, and parallel to, the section that is lying on the metal knife. When the slide is abouts $2 \mathrm{~mm}$ from the knife, there is a temperature gradientoof +20 to $-70^{\circ} \mathrm{C}$ across the section; water boils off 3 . the section (without having time to crystallise into ice) on to the colder surface, and this rapid evaporation ejects the dry section on to the glass slide. Ano imprint of the section, in water (which freezes rapidly), is left on the knife. The relatively dryo section can now safely be removed from the cabinet. The validity of these procedures has been considered $O$ in detail by Chayen and Bitensky ${ }^{15}$ and by Chayen. ${ }^{17}{ }^{18 N}$

When ultra-thin sections, prepared from such స్ట thicker sections, have been examined by electron- $\sigma$ microscopy, no evidence of ice-artifact has been observed. ${ }^{19} 20$

\section{Thickness of sections}

In general, cytochemical studies on sections involve comparison of the amount of the coloured reaction- $\mathbb{\Phi}$ product, developed by the chemical activity in one $\frac{?}{\mathbb{D}}$ section, with that developed in another section. But $\frac{\varrho}{\sigma}$ the actual amount of reaction-product must depend 
on the amount of the chemical activity present, and this will depend on the thickness of the section. Indeed, it is one of the essential checks, that should be made of all cytochemical reactions, that the reaction is linear with thickness. Yet, as is familiar to histopathologists, serial sections, even of paraffin blocks, are rarely of exactly the same thickness even though they are cut at a nominal constant thickness.

This question was investigated by Butcher. ${ }^{21} \mathrm{He}$ determined the nucleic acid content of a mass of liver and, knowing the density of the liver, he could convert the results (mass of DNA/mg liver) to concentration of nucleic acids per volume (mass of $\mathrm{DNA} / \mathrm{mm}^{3}$ ). From this he was able to define the amount of nucleic acids that should be expected to occur in tissue sections, of measured surface area and of nominal 8,10 , or $14 \mu \mathrm{m}$ thickness, taken from the same liver. Thus he cut cryostat sections; measured the planar area; and extracted the nucleic acids, which he measured spectrophotometrically. From such measurements he could derive the actual thickness of the sections. His finding was that the actual thickness depended on the speed at which the tissue-block passed across the knife. For example, with the cryostat set to a nominal thickness of $14 \mu \mathrm{m}$, the actual thickness of sections cut quickly was $9.8 \mu \mathrm{m}$, whereas it was $19 \mu \mathrm{m}$ if he cut slowly. For this reason it has become routine practice to cut cryostat sections by means of an automatic device that ensures a constant speed of cutting. Under these conditions, where variations in thickness have been monitored either by interference microscopy or by the amount of coloured reaction-product in several serial sections, the thickness has been constant to better than $\pm 4 \%{ }^{17} 18$

\section{REACTIONS}

\section{General}

It deserves to be stressed that cytochemical reactions should be done under defined optimal conditions, as should pertain to all properly conducted biochemical assays. Optimal concentrations of all reactants (and this includes $\mathrm{pH}$ ) ought to be determined for each enzyme, or reactive group, investigated in each tissue. Except for particular circumstances, the reactions should be shown to be linear with time and with thickness of sections (ie, with the concentration of the enzyme or reactive-group). These tests do not take undue time, and can avoid much subsequent disappointment.

\section{Stabilisation of sections}

The dilemma of thoughtful histochemists and cytochemists has been the following: the proteins and ribonucleoproteins of the cytoplasm readily dissolve, or at least disperse, into ionic solutions at $\mathrm{pH}$ values of 7-8; therefore unfixed sections of tissue, containing undenatured protoplasm, lose about $50 \%$ of their nitrogenous content when immersed in normal biochemical reaction media at these $\mathrm{pH}$ values. Thus it was virtually impossible to measure normal oxidative activity in unfixed cryostat sections since the optimal $\mathrm{pH}$ for most of these reactions is within these pH-limits. To some extent, much of the nitrogenous matter can be preserved by chemical fixation but such fixation, by its very nature, destroys some or much of the biochemical activity that is sought. ${ }^{9}$ The problem was overcome by the finding that certain substances, that are much used commercially to stabilise colloidal suspensions, also stabilise unfixed, cryostat sections, retaining all the nitrogenous matter and all the "soluble" enzymatic activity that has been examined.151718 22-5 Moreover, it has been shown that the sections can be stabilised without causing inhibition of the enzymatic activity. ${ }^{6}$ The following stabilisers have been used in various studies: particular grades of polyvinyl alcohol;22 26 a partially degraded collagen (available from Sigma as Polypep 5115); ${ }^{25}$ Ficoll, especially for blood cells; ${ }^{10}$ and gum tragacanth. ${ }^{27}$

\section{MEASUREMENT}

Many of the methods used in cytochemistry are also used in conventional biochemistry. These include the use of tetrazolium salts, either alone or together with the intermediate hydrogen-acceptor,phenazine methosulphate, for assaying the activity of oxidative enzymes, and the use of naphthylamidase reactions for assaying enzymes that cleave peptide bonds. In conventional biochemistry, the coloured reaction products are measured in solution; consequently they can be measured by conventional spectrophotometry. In contrast, the cytochemical reaction products occur as precipitates, close to the site of the enzymatic activity. Simple photometry would cause totally unacceptable errors in such measurements, as has been discussed again recently by Chayen ${ }^{6} 18$ and by Bitensky. ${ }^{8}$ The optical inhomogeneity error, or distribution error, caused by the presence of an inhomogeneously distributed chromophore, is overcome by measuring each optically homogeneous area separately, by means of a flying-spot, and summating all the readings. In the extreme case, and for maximal precision, the diameter of the flying-spot should be about $0.25 \mu \mathrm{m}$ in the plane of the specimen.

In practice, the section is reacted for the particular biochemical activity to be studied. The cytochemical reactions should produce a coloured precipitate in the active cells; the amount of the precipitate should be stoichiometric with the amount of the biochemical activity present in each cell. 
The section is then placed on the stage of the microdensitometer, which basically is a spectrophotometer built around a conventional microscope (Fig. 1). The histology of the tissue section is determined by conventional microscopy, aided by phase-contrast microscopy when required, and the target-cells are defined. An optical mask is placed on the first of these cells (or on a specific part of one of thesecells, or on a group of the target-cells, depending on the reaction and on the form that the measurements are to take). This mask instructs the microdensitometer to accept measurements only from within the area delimited by the mask. The wavelength of the light, which should be that at which the chromophore absorbs maximally when present in the $\frac{\text { \% }}{\text { के }}$ section, is then selected as is a suitable size for the flying-spot. The latter is then sent over the whole $\overrightarrow{\vec{F}}$ field, in a raster pattern, and the instrument summates-? the amount of light absorbed by all the sites traversed ${ }_{0}$ by the flying-spot within the optical mask. This $\overline{\overline{0}}$. value, the relative absorption, is recorded on a $\vec{\Phi}$ digital meter; each integrated reading takes about $\varrho$ three seconds.

The relative absorption is a logarithmic conversion $\overrightarrow{0}$ (as is required for extinction, or absorbance) of the total absorption within the area of the mask. Its $\omega_{\sigma}$ precise value will depend on the electronic character-승 istics of the instrument, so that such measurements?

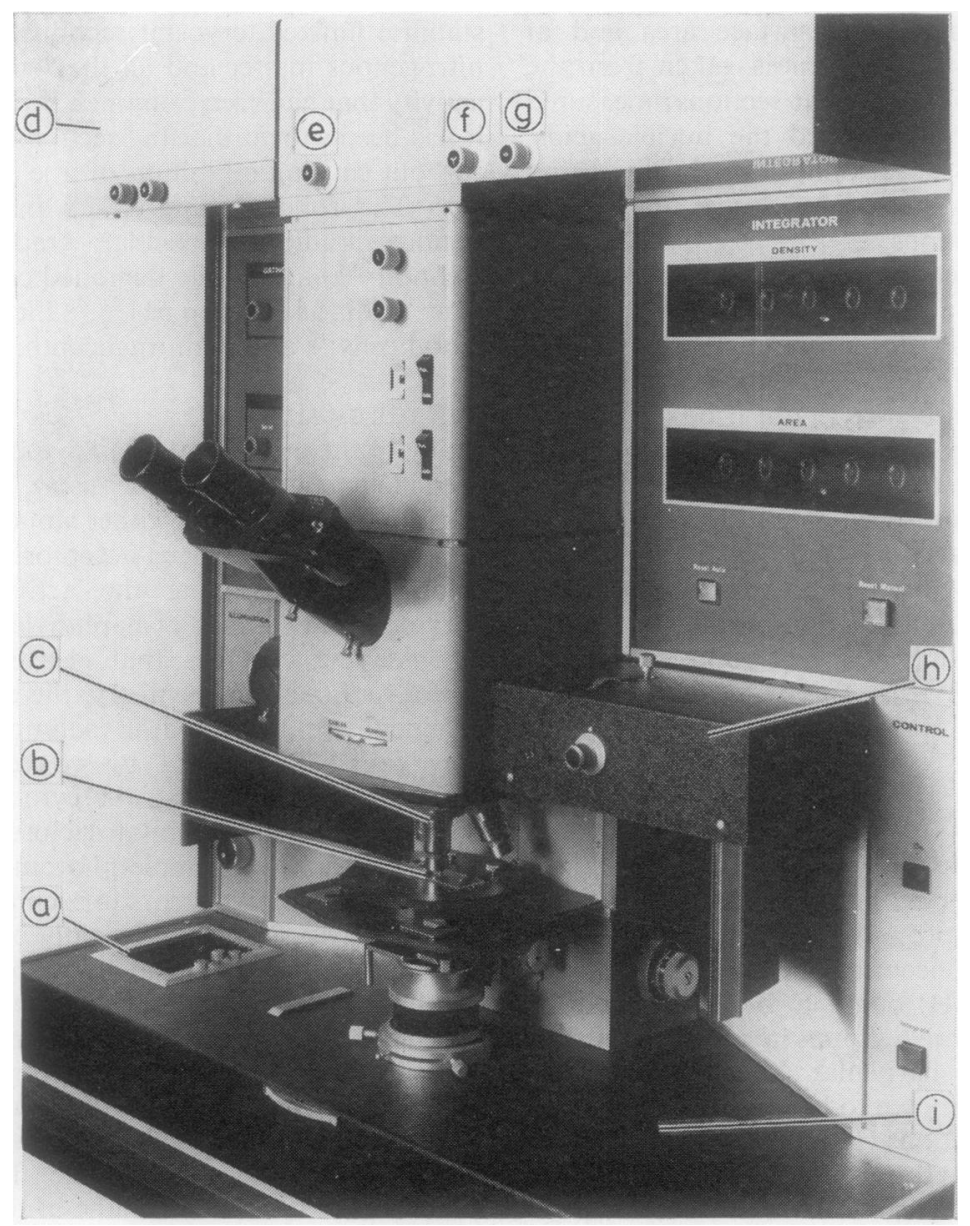

Fig. 1 Vickers M85 scanning and integrating microdensitometer. (a) viewing lamp for normal microscopy; (b) specimen on microscope slide; (c) objective; (d) measuring (spectrophotometer) lamp; (e) band-width control; $(f)$ wavelength control (monochromator); $(g)$ flying-spot diameter control; (h) housing containing the monitoring photomultiplier; (i) housing for the measuring photomultiplier. 
(of relative absorption) will be acceptable for comparative studies, made with one microdensitometer. However, such measurements cannot be compared with absolute measurements of extinction (or absorbance, or optical density) made spectrophotometrically, or with similar measurements made on other microdensitometers. Consequently the readings of relative absorption are frequently converted to "mean integrated extinction" by means of a calibration graph that relates absolute extinction to the amount of relative absorption, recorded for a particular magnification and a specified mask-area, when the field consists of a neutral density filter of known absolute extinction. 68 This "mean integrated extinction" represents the mean extinction (in absolute units, as in the Beer-Lambert equation for spectrophotometry) of all the readings made by the flying-spot. Normally it is recorded as "mean integrated extinction (MIE) $\times 100$ " $($ MIE $\times 100)$ so that an MIE $\times 100$ of 32 is equal to an absolute mean extinction of 0.32 in the selected field or cell. However, it is exclusive of the area over which this mean extinction pertains, so that frequently it is preferable, for comparative studies, to use the relative absorption recorded by the instrument under the defined conditions.

Generally the variation between target cells within any one section, and between duplicate sections, is so small that it suffices to make 10 or 20 readings in the target cells from each of two serial sections.

\section{Present state of cytochemistry}

The developments in cytochemistry, discussed above, have transformed this subject into a precise form of cellular biochemistry, capable of measuring metabolic changes, however these are induced, in specific target cells even if these are dispersed within a tissue of complex histological structure. Some of the many applications of this subject, to diverse branches of medicine, have been described recently. ${ }^{28} \mathrm{It}$ seems likely that, in its ability to detect biochemical changes that may be characteristic of certain diseases, and may precede histological abnormalities, cytochemistry can be used as a form of chemical pathology, linking histopathology with clinical biochemistry. However, the current major interest in cytochemistry is related to its measurement of biochemical changes caused by hormones acting on their target cells, and to the assay of the concentration of the hormone.

\section{Need for sensitive bioassays}

DIFFERENT TYPES OF ASSAYS

Hormones can be assayed by two quite different types of procedure: by functional or by analytical assays. ${ }^{18} 29$ The former, which includes all bioassays, measures the concentration of the hormone by the amount of some biological function that it causes; fundamentally, the second measures the number of molecules of the same specific type as the hormone. The basis of the analytical assays, of which radioimmunoassay is a good example, is that there is a relationship, or a stoichiometry, between a specific molecular structure and a particular biological function.

\section{EARLIER BIOASSAYS}

Initially, hormones were defined by what they did. For example, the adrenocorticotrophic hormone (ACTH) stimulated the cortex of the adrenal gland both trophically and so as to stimulate secretion of its products, notably cortisol in man, or corticosterone in some other mammals. Hence it was reasonable to assay this hormone, let us say in human plasma, by injecting the plasma into the adrenal gland of rats and to measure the amount of corticosterone secreted by that gland. This is done in the in vivo bioassay described by Lipscomb and Nelson. ${ }^{30}$ Equally it may be more convenient to measure a correlate of the final physiological response to the hormone. Thus Sayers et al. ${ }^{31}$ found that there was a direct relation between the concentration of ACTH acting on the adrenal gland, and the depletion of ascorbate from the gland; they therefore assayed ACTH by the degree of depletion of ascorbate. At that time it only seemed likely that there must be a direct causal relation between ascorbate-depletion and ACTH-secretion but, for all that, this was a valid functional test.

The great drawback to the conventional bioassays done in vivo was their low sensitivity, so that it was rarely possible to measure normal circulating concentrations of polypeptide hormones by these methods. For example, the limit of sensitivity of the Lipscomb-Nelson bioassay of ACTH is about $100-200 \mathrm{pg} / \mathrm{ml}$, whereas the mean circulating level in groups of normal individuals may range from 24 to $70 \mathrm{pg} / \mathrm{ml}$, at different times of the day. ${ }^{32}$ Consequently the Lipscomb-Nelson bioassay was useful only in those conditions in which abnormally high concentrations of ACTH are found.

\section{ROLE OF RADIOIMMUNOASSAY}

It was therefore to be expected that radioimmunoassay (and now the other forms of immunoassay) with its greatly improved sensitivity, would replace the older in vivo bioassays. All these analytical assays measure the concentration of specific antigenic determinants that are characteristic of the polypeptide hormone. In the earlier days, it was easier to 
prepare antibodies to the species-specific, but apparently biologically inactive, region of the polypeptide chain. It was well recognised that results with such antibodies could be misleading if the polypeptide chain was cleaved to yield longer-lived, biologically-inactive regions that reacted with the antibody. However, at present, many immunoassays use antibodies raised against the biologicallyactive sequences of the polypeptide hormone and therefore should, apparently, measure the number of biologically active peptide-sequences that are present in the circulation. Unfortunately, it has proved less simple than this. It seems ${ }^{33}$ that an antibody responds to a sequence of four or perhaps five amino acids. Consequently, if the biological activity of ACTH resides in the $\mathrm{N}$-terminal 24 amino acids, or that of parathyroid hormone in the N-terminal 34 amino acids, there is plenty of scope for cleavage within the biologically active sequences to provide biologically inert fragments that are sufficiently large to be recognised by the antibodies. Thus the discrepancies that have been reported between the results obtained by the older bioassays and by radioimmunoassay have been considered to be due to such biologically inactive, but immunologically potent, fragments. ${ }^{34}{ }^{35}$ The danger of immunologically similar determinants has recently been emphasised by Guillemin et al. ${ }^{36}$ The difficulties are compounded by the further possibilities that the polypeptide sequence may be intact and yet lose biological activity by virtue of a molecular configurational change ${ }^{37}$ or that it may be part of a "big-form" of the molecule (like big $\mathrm{ACTH}$, or big big gastrin) ${ }^{38}$ or of a precursor of the hormone; all such forms possibly having relatively little biological activity.

Thus the basic premise of analytical assays, namely that there is a direct relation between the number of specific antigenic determinants and the biological activity normally associated with the hormone molecule, has been seriously called into doubt. Despite this, as a quick screening technique and for most purposes, radioimmunoassay is invaluable in clinical endocrinology. Moreover, the apparent disadvantage of measuring number of molecules, rather than biological activity, has its own peculiar advantage. This arises from the fact that it is now apparent that many tumours secrete molecules that resemble those of polypeptide hormones but lack much, if not all, biological activity. Such "ectopic production of hormones"39-41 can be of considerable diagnostic value;42 they can be detected and assayed only by immunoassay, not by bioassay.

WHO RECOMMENDATION

The World Health Organisation, through its Expert Committee on Biological Standardisation, is re- sponsible for establishing international reference standards and international units by which hormones can be measured. Even as early as 1967, during the more euphoric phase of radioimmunoassay, a meeting convened by this organisation recognised that "... a limitation on the use of immunoassays for evaluating hormonal bioactivity is that the methods measure a composite of antigenic activity, which is not necessarily related to the bioactivity of the hormone . . ." and called for ". . . the development of biological microassays, which should preferably have a sensitivity comparable with radioimmunoassays, with which they should be run in parallel."43

The main "biological microassays" that have been developed since 1967 have been the isolated cell bioassays and the cytochemical bioassays. Among the former are the isolated adrenal cell bioassay of Sayers et al. ${ }^{44}$ for ACTH, and the isolated Leydig cell assays for luteinising hormone. ${ }^{45} 46$ In each case, the concentration of the hormone applied to the cells is measured by the amount of the physiological response normal to that hormone: corticosterone produced by the adrenal cells, or testosterone produced by the Leydig cells. These isolated cell bioassays, and the cytochemical bioassays, conform to the WHO requirements. The particular advantage of the cytochemical bioassays is that the same apparatus and general procedures can be applied to the bioassay of many (possibly to all) polypeptide hormones simply by changing the target-tissue and the cytochemical reaction. Furthermore, it is now apparent that the cytochemical bioassay system is flexible so that it is now being used to detect and measure the effects of biologically active immunoglobulins. Apart from these advantages over isolated cell bioassays, the cytochemical bioassay system has two other advantages: firstly that the assays are more sensitive, so that they require very little material for measuring normal circulating concentrations and can explore the pathology of subnormal concentrations; and secondly that by judicious use the system can discriminate between related molecules. ${ }^{17} 1829$

\section{Basic procedures of the cytochemical segment bioassays}

\section{BASIC CONCEPTS}

\section{Response and specificity}

When a polypeptide hormone acts on its target cells it causes metabolic changes that lead to the physiological manifestations by which the hormone is recognised. For example, when ACTH acts on the adrenal cortex it changes the biochemical activities 
of these cells towards the secretion of cortisol. One of these changes may involve the depletion of ascorbate, the possible role of which has been discussed by Chayen et al., ${ }^{29}$ also Chayen. ${ }^{18}$ As has been explained above, cytochemistry is now so developed that it can measure such biochemical changes, and measure them solely in the target-cells. So, to retain the same example, the basis of the cytochemical bioassay of ACTH is the measurement of the degree of depletion of ascorbate from the most affected cells, namely those of the zona reticularis.

The fact that the biochemical change that is measured is one that influences the physiological manifestation of the hormone, adds to the specificity of these assays (Table 1). This arises from the present understanding of how polypeptide hormones act. The first specific effect is believed to be the binding of the hormone to its specific receptor. This is the basis of binding-assays. But there is no evidence that all binding invokes the typical biological response. The second effect involves some biological response to the binding of the hormone; typically this is the stimulation of adenylate cyclase activity, or some comparable system. However, in view of the many stimuli that can evoke such activity, it is not certain that this may not be a generalised response to sufficient perturbation of the cellular membranes. But for true hormonal action, the binding and the stimulation of the second messenger, be it a cyclic nucleotide or calcium or some other substance, must be directed to a specific biochemical mechanism, within the cell, that will produce the physiological response to the hormone. And it is a component of this last effect that is measured in the cytochemical bioassays.

Table 1 Specificity of the biological response in the cytochemical bioassay system

\begin{tabular}{cc}
\hline In the cytochemical bioassay system & Comment \\
\hline $\begin{array}{c}\text { (1) Specific binding to the receptor } \\
\text { on the target cell }\end{array}$ & $\begin{array}{c}\text { Compare, for example, } \\
\text { receptor-ligand systems } \\
\text { Compare, for example, } \\
\text { adenylate cyclase assays }\end{array}$ \\
$\begin{array}{c}\text { (2) Generation of the second } \\
\text { messenger }\end{array}$ & $\begin{array}{c}\text { Additional specificity in the } \\
\text { cytochemical bioassay } \\
\text { (3) Specific message that alters the } \\
\text { biochemical activity in the } \\
\text { target cell to produce } \\
\text { physiological response }\end{array}$ \\
\hline
\end{tabular}

\section{Tissue and sensitivity}

Firstly, in order to achieve a high degree of sensitivity, the assays have to be "within-animal" assays, that is, they have to be done on tissue from one animal. Only in this way can they avoid the relative imprecision imposed on the older, in vivo bioassays by the great variability that is found in tissues from different animals, even from litter-mates. Secondly, it must be recognised that the biochemical activities to be measured will be stimulated, in the living animal, by the hormone circulating in the blood of that animal. It is therefore necessary to remove the tissue from the activity of endogenous hormone so that the biochemical activities, normally stimulated by the hormone, will subside to basal levels. Frequently this is achieved by the surgical removal of the gland that produces the hormone, for example by hypophysectomy to remove ACTH, or by parathyroidectomy to remove the parathyroid hormone. It is achieved more simply in the cytochemical bioassays by removing the target-tissue, cutting it into segments, and then maintaining the segments in non-proliferative organ-maintenance culture ${ }^{47}$ for $5 \mathrm{~h}$. During this time, the influence of the hormone that was endogenous to the animal wanes, leaving the biochemical systems at a basal level from which they can be stimulated even by very low concentrations of the hormone. Moreover the five-hour maintenance in vitro allows the tissue to recover from the trauma of excision, which can severely affect the ability of the cells to respond to the hormone. ${ }^{1829}$

\section{GENERAL PROCEDURE}

Whenever practicable, guinea-pigs are used because generally they are more responsive than rats. Whichever animal is selected, it is killed by asphyxiation with nitrogen, to avoid the deleterious effects on membranes that may be caused by anaesthetics.

The target organ is removed expeditiously and cut into segments. Normally six segments can be obtained from the cortex of two adrenal glands or from one thyroid gland (used in the assay of thyroid stimulators). Many segments can be obtained from the renal cortex (for assaying parathyroid hormone) or from the gastric fundus (for assaying gastrin-like activity). Each segment is maintained individually for $5 \mathrm{~h}$, at $37^{\circ} \mathrm{C}$, in Trowell's $\mathrm{s}^{47}$ non-proliferative organ culture. In this system the segment is placed on a layer of defatted optical lens tissue, lying on a table fashioned from open stainless steel mesh. This table is placed in a vitreosil glass dish $(40 \mathrm{~mm}$ diameter) and Trowell's synthetic T8 medium, with or without additives, is added to the dish up to the lower level of the lens tissue. In this way, the segments receive nutrients through the lens tissue; they are not immersed in fluid because such immersion decreases the responsiveness of the cells. The vitreosil dish is placed in a plastic pot $(8 \times 4 \mathrm{~cm})$, with a tight-fitting lid that has inlet and outlet tubes; the lid is sealed to the pot by means of lanoline (Fig. 2). The atmosphere inside the pot is replaced by one containing $95 \%$ oxygen: $5 \%$ carbon dioxide, the latter being required also to buffer the bicarbonate in the $\mathrm{T} 8$ medium to $\mathrm{pH} \mathbf{7 \cdot 6}$. 


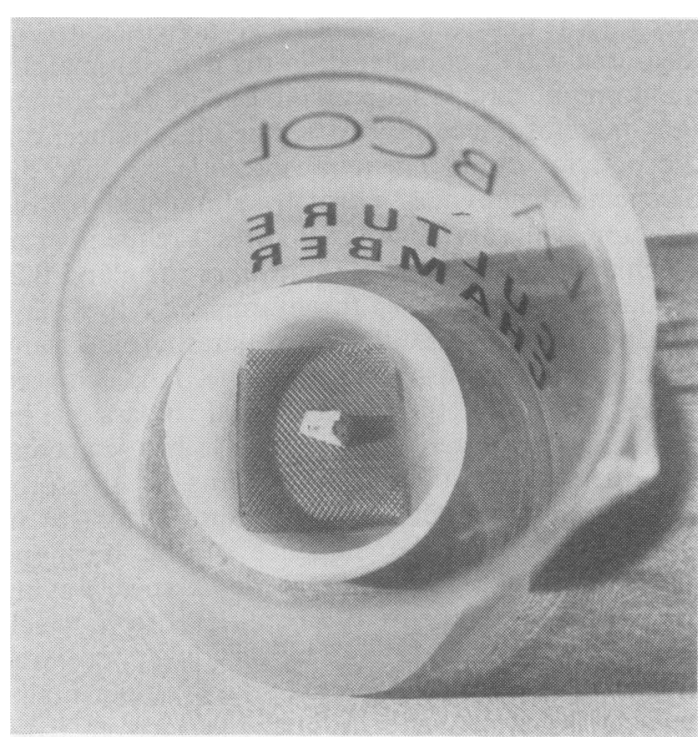

Fig. 2 The culture chamber viewed from above (without lid), showing the tissue sitting on the metal-mesh table inside the vitreosil dish.

In some assays, essential metabolites (such as ascorbate in the ACTH assays) are added to the T8 medium. In the assay of gastrin-like activity, the $\mathrm{pH}$ of the medium may be altered by changing the amount of bicarbonate in the medium. For the parathyroid hormone assay, the guinea-pigs are kept on a diet that is supplemented with vitamins, to ensure sensitive responses. Thus the selection of the conditions of the animal (size and weight) and the conditions of maintenance culture involve some study of the endocrine physiology relevant to the assay.

At the end of the five-hour period, the medium is removed and replaced by fresh medium containing the hormone. Each of four segments is exposed to one of a logarithmically graded series of concentrations, in the T8 medium, of a standard reference preparation of the hormone-for example, $5 \mathrm{fg} / \mathrm{ml}$ to $5 \mathrm{pg} / \mathrm{ml}$ inclusive. These will provide the calibration graph. One of the other segments is exposed to the first dilution of the plasma, usually $1 / 100$ in T8 medium; the other (if only six segments are available) receives the plasma at tenfold dilution -for example, 1/1000. After the hormone has been allowed to act for the previously determined optimal time, the segments are chilled to $-70^{\circ} \mathrm{C}$. Later they are sectioned and the selected biochemical response, in the target-cells, is measured by the cytochemical procedures that have been described above.

The selection of a suitable biochemical change, induced by the hormone, and the precise timing of the assay, depend on having previously defined the metabolic events invoked by the hormone. Thus the development of these cytochemical bioassays has involved studies on the way these hormones function. Indeed, one of the advantages of the cytochemical bioassay system is that it is a means for investigating the details of how hormones act at the cellular level. In particular, the effect of thyroid stimulators, bound at the surface of the target cells, in activating the lysosomal membranes deep inside the cytoplasm, has been the object of some interest. It has been shown that, in this case at least, the hormone appears to act by stimulating the synthesis of polyamines; it is likely that it is the influence of these polyamines, especially spermidine, that causes the lysosomal labilisation for the endocytosis and processing of colloid. ${ }^{48}$

\section{GENERAL RESULTS}

Apart from the segment assay of thyrotrophin, which yields a curvilinear response, ${ }^{49}$ all the cytochemical bioassays have calibration graphs which show a linear relation between the logarithmic concentration of the reference preparation of the hormone and the biochemical activity measured (Fig. 3). Normal plasma, diluted logarithmicallyfor example, $1 / 100,1 / 1000$, regularly gives a parallel response, from which the concentration of the hormone in the plasma can be derived from comparison with the calibration graph. Thus, for example,

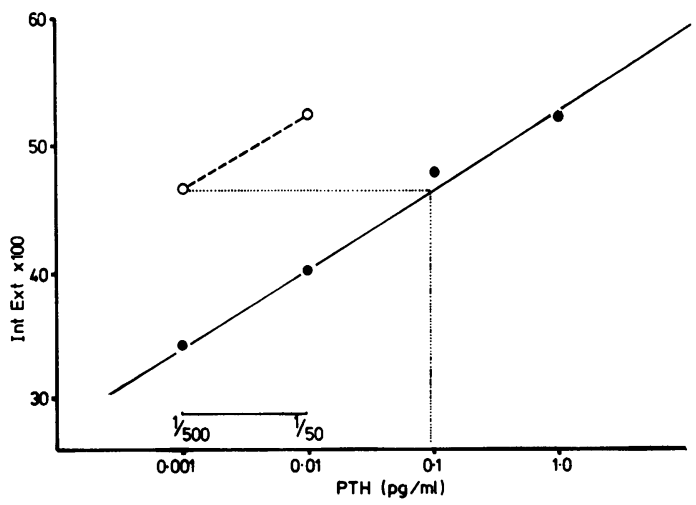

Fig. 3 A standard calibration graph (O) for a segment assay for parathyroid hormone $(P T H)$ relating the logarithmic concentrations of the standard preparation of the hormone to the biochemical activity (glucose-6phosphate dehydrogenase activity in the distal convoluted tubules: mean integrated extinction (Int Ext) $\times 100$ ). The broken line links the activities in the presence of two dilutions (1/50 and 1/500) of a sample of human plasma: there is good parallelism of response. The dotted lines show how the extinction value, for one of the samples, is related to the concentration of the hormone present at this dilution. 
if the mean absorption (Int Ext $\times 100$ ) in the target cells is $\mathbf{4 7}$ units (as in Fig. 3), a line is drawn from this point in the calibration graph to intersect with the standard calibration graph. The concentration of the standard preparation of the hormone equivalent to this absorption (shown by a dotted line in Fig. 3 ) is read off the horizontal axis. Thus, for the $1 / 500$ dilution, shown in Fig. 3, the concentration of parathyroid hormone in this sample would be 0.95 $\mathrm{pg} / \mathrm{ml}$. Correcting for the dilution factor of $1 / 500$, this means that the original plasma contained $47.5 \mathrm{pg} / \mathrm{ml}$, as is found in patients with hyperparathyroidism. The same procedure is then applied to the less diluted $(1 / 50)$ sample. The precision of bioassays is assessed by their index of precision, which is the variance of the pointsabout the regression line divided by the slope $\left(S_{\mathrm{y}} \mathrm{x}\right) / \mathrm{b}$. For an assay to be useful, the index of precision $(\lambda)$ should not exceed 0.2 , although a $\lambda$ of 0.3 can sometimes be used. ${ }^{50}$ The index of precision of all the cytochemical bioassays is around or below $0 \cdot 1$ (Table 2).

The variation in response between serial sections of the same tissue block has been measured for several of these assays: thyrotrophin;49 ACTH;51 gastrin $; 52$ it has been within $\pm 5 \%$, so validating the use of an automatic device for cutting sections of uniform thickness. Different segments exposed to the same concentration of hormone yielded results that agreed to within $\pm 3 \% \%^{51}$ The specificity of the assays has been shown (i) by the fact that the addition to the plasma of an antibody specific to the hormone largely neutralised $(90 \%$ or more) the activity of the plasma, (ii) by the lack of activity shown in this test by related substances; and (iii) by the fact that the activity, measured by the assay, fluctuated in accord with physiological conditions that would alter the circulating concentration of the hormone. For example, intravenous injection of cortisol $^{53}$ decreased the circulating concentration of ACTH, as measured in the appropriate cytochemical bioassay, from $43 \mathrm{pg} / \mathrm{ml}$ to $34 \mathrm{fg} / \mathrm{ml}$ with a calculated half-life that agreed well with previous estimates, made by a different bioassay. ${ }^{54}$ Similarly, prolonged treatment of volunteers with thyroxine decreased the circulating concentrations, of what was measured in the cytochemical bioassay for thyrotrophin, from 0.33 to $0.018 \mu \mathrm{U} / \mathrm{ml}^{55}$ Thus in these and other tests, the material that was measured by the cytochemical bioassay behaved as would be expected of the hormone, so strengthening belief in the specificity of these bioassays.

\section{Cytochemical section-bioassays}

DEVELOPMENT OF THESE ASSAYS

The need to check the biological activity of samples that produced unexpected results by radioimmunoassay is so general that the cytochemical bioassays found ready acceptance. But, because of this need, there was an urgent demand for cytochemical bioassays with a greater "through-put" than obtains with the segment-assays. The relative slowness of these segment-assays is due to the fact that, for the precision attained by these methods, they have to be "within-animal" assays. Thus four segments are used to obtain the calibration graph that shows how the target-cells from this particular animal respond to standard concentrations of the hormone in vitro. It is rare to be able to cut more than six segments from many target organs, so that

Table 2 Current cytochemical bioassays ${ }^{18}$

\begin{tabular}{|c|c|c|c|c|c|c|}
\hline $\begin{array}{l}\text { Hormone or } \\
\text { biologically-active } \\
\text { substance }\end{array}$ & Target cells & Biochemical change & Biological function & $\begin{array}{l}\text { Sensitivity } \\
(\text { per } m l)\end{array}$ & $\begin{array}{l}\text { Index of } \\
\text { precision }\end{array}$ & Reference \\
\hline $\begin{array}{l}\text { Adrenocorticotrophic } \\
\text { hormone }\end{array}$ & Zona reticularis & Ascorbate depletion & Steroidogenesis & $5 \mathrm{fg}$ & $0.05-0.09$ & Daly JR et al. ${ }^{51}$ \\
\hline Thyrotrophin & Thyroid follicle cell & Lysosomal activation & Production of T3, T4 & $4 \times 10^{-5} \mu \mathrm{U}$ & U $0 \cdot 1$ & Chayen $\mathrm{J}$ et al. ${ }^{27}$ \\
\hline $\begin{array}{l}\text { Thyroid-stimulating } \\
\text { immunoglobulins }\end{array}$ & Thyroid follicle cell & Lysosomal activation & Production of T3, T4 & 一 & - & Bitensky L et al.“" \\
\hline $\begin{array}{l}\text { Thyroid growth } \\
\text { stimulators }\end{array}$ & Thyroid follicle cell & DNA synthesis & Growth (goitre) & - & - & Drexhage HA et al. ${ }^{63}$ \\
\hline $\begin{array}{l}\text { Luteinising hormone } \\
\text { Gastrin }\end{array}$ & $\begin{array}{l}\text { Corpus luteum } \\
\text { Parietal cells }\end{array}$ & $\begin{array}{l}\text { Ascorbate depletion } \\
\text { Carbonic anhydrase }\end{array}$ & $\begin{array}{l}\text { Steroidogenesis } \\
\text { Acid secretion }\end{array}$ & $\begin{array}{l}10^{-4} \mathrm{mU} \\
5 \mathrm{fg}\end{array}$ & $\begin{array}{l}0 \cdot 12 \\
0 \cdot 1\end{array}$ & $\begin{array}{l}\text { Buckingham JC et al. }{ }^{56} \\
\text { Loveridge } \mathrm{N} \text { et } \text { al. }{ }^{52}\end{array}$ \\
\hline $\begin{array}{l}\text { Gastrin-blocking } \\
\text { immunoglobulins }\end{array}$ & Parietal cells & Carbonic anhydrase & $\begin{array}{l}\text { Inhibition of acid } \\
\text { secretion }\end{array}$ & - & - & Loveridge $\mathrm{N}$ et al. ${ }^{\star 1}$ \\
\hline Parathyroid hormone & $\begin{array}{l}\text { Distal convoluted } \\
\text { tubules }\end{array}$ & $\begin{array}{l}\text { Glucose 6-phosphate } \\
\text { dehydrogenase }\end{array}$ & Calcium resorption & $5 \mathrm{fg}$ & $0 \cdot 12$ & Chayen $\mathbf{J}^{18}$ \\
\hline $\begin{array}{l}\text { Thyrotrophin-releasing } \\
\text { hormone }\end{array}$ & Pituitary & $\begin{array}{l}\text { Production of } \\
\text { thyrotrophin }\end{array}$ & & 一 & 一 & Chayen $\mathbf{J}^{18}$ \\
\hline $\begin{array}{l}\text { Corticotrophin-releasing } \\
\text { factor }\end{array}$ & Pituitary & $\begin{array}{l}\text { Production of } \\
\text { adrenocorticotrophic } \\
\text { hormone* }\end{array}$ & & - & - & Chayen $\mathrm{J}^{18}$ \\
\hline
\end{tabular}

* Measured by the appropriate cytochemical bioassay.

tIndex of precision = variance of points around regression line divided by the slope. 
only two segments remain for testing the plasma. And each sample must be tested at two concentrations, to establish that the response is parallel to that with the reference preparation of the hormone. Hence even with the kidney, or the stomach, from which more than six segments can be selected, the restriction is that four segments must always be devoted to producing the calibration graph. Even if 12 segments can be prepared from these tissues, only four plasma samples can be assayed from the tissue of one animal.

It is not practicable to use even smaller segments to increase the number of assays per animal. But the logical extension of this idea would be to use sections, instead of segments. This seemed to be a fanciful idea: the cells in the sections would have to retain the ability to bind the hormone; to respond to the binding by the production of a "second messenger"; and then to change their metabolic activity in response to the hormone (Table 1). It could have been argued that cells in a block of tissue that had been "frozen," sectioned at low temperature, and then "flash-dried," were unlikely to retain all the vital attributes necessary for such a performance. Against such doubts it could be argued that tissue slices, or subcellular fractions of cells, isolated by conventional biochemical procedures, can perform a wide repertoire of biochemical activities that normally occur in intact, living cells; moreover, the procedures to which the tissue is exposed in modern cytochemical processes are designed to protect the cells considerably more than are current biochemical methods.

In fact, it has been found that cells in sections, prepared as described above, can respond fully to the hormones, and do so with the same sensitivity as they show when they are part of a relatively large segment that is exposed to hormone in maintenance culture. This seems to be an additional validation that the processes of chilling, cryostat-sectioning, and flash-drying do not seriously alter the biochemical state of the cells in the segments. Thus this adds to the confidence with which one can analyse the cytochemistry of biopsies for analysing diseaseprocesses that may have occurred in vivo.

The special requirements that had to be met in preparing cytochemical section-assays were: (i) that the sections had to be just thicker than the relevant dimension of the target-cells, so ensuring that most of the target-cells in the sections were relatively intact; and (ii) that during exposure to the hormone, generally at a $\mathrm{pH}$ of about $\mathrm{pH} 7 \cdot 6$, the sections were sufficiently stabilised (with a colloid-stabiliser, as discussed above) to retain their activities while not being so well stabilised that they would not respond even to the hormone. Obtaining a suitable balance for the second requirement was often a long and awkward task. But once this was achieved, it was possible to assay a large number of samples of plasma all on the same piece of one organ: in the sectionassay of luteinising hormone, ${ }^{56}$ about 10 samples (all at two dilutions, and together with the calibration graph) can be measured on a single corpus luteum, so taking the idea of "within-animal" assays to its extreme.

GENERAL PROCEDURE FOR CYTOCHEMICAL

SECTION-ASSAYS

The target organ is removed and cut into segments, as for the segment-assays except that the segments can be larger (eg, each thyroid lobe, or adrenal gland, can be cut into two instead of three). The segments are maintained in vitro for $5 \mathrm{~h}$, as for the segmentassays, and for the same reasons. At the end of this $O$ period the segments are chilled to $-70^{\circ} \mathrm{C}$. They can 을 be used only over the next two days as sensitivity of $\overrightarrow{ }$ response declines thereafter. In some cases, just $\overleftarrow{\epsilon}$ before the segment is chilled it is "primed" with the hormone; that is, it is treated with one-tenth of the concentration of the hormone that can be detected $\stackrel{\infty}{\oplus}$ by the assay, and for a period that would result in the maximal response to measurable concentrations of the hormone.

Sections are cut of the chilled segment, as has been described above, except that the thickness depends on the thickness of the target-cells. Thus for assaying ACTH the sections are cut at $20 \mu \mathrm{m}$, the largest dimension of the cells of the zona reticularis, in our preparations, being about $18 \mu \mathrm{m}$. The sections are then clipped together, in duplicate, back-to-back, in the lid of an apparatus; the base contains separate compartments so that each pair of sections locates in ? its own compartment when the lid is in position. The $\frac{3}{3}$ first four compartments contain the four graded concentrations of the reference preparation of the hormone, as is required for the calibration-graph. The next two compartments contain the two dilutions of the first sample to be assayed, normally at $1 / 100 \frac{7}{0}$ and $1 / 1000$ dilution; the next two contain the dilutions of the second plasma, and so on. One pair $N$ of compartments can be used for a quality control $N$ sample.

The cells in sections respond much more rapidly than they do when they are in a segment. For example, the maximal response to ACTH is $5 \mathrm{~min} \stackrel{0}{\mathrm{C}}$ in segments, but $60 \mathrm{~s}$ in sections; the comparable figures for thyrotrophin are $7 \mathrm{~min}$ and $90 \mathrm{~s}$.

After the sections have been exposed for the requisite time to the hormone, the lid is removed $\frac{\vec{D}}{\mathrm{D}}$ (together with all the sections) and placed on a trough $\frac{\rho}{\Phi}$ that contains the freshly prepared cytochemical $\stackrel{\mathbb{D}}{2}$ reaction-medium for disclosing the biochemical $\widetilde{\sigma}$ 
activity that is used as the indicator of the effect of this particular hormone (as for the segment-assays). The cytochemical reaction is developed, and the activity, in the target-cells, is measured by microdensitometry.

The section-assays have the same sensitivity, specificity and precision as the segment-assays.

\section{Comparison of cytochemical bioassays with radioimmunoassays}

The cytochemical bioassay (CBA), radioimmunoassay (RIA) and the Lipscomb-Nelson ${ }^{30}$ in vivo bioassay were all done, with suitable standard preparations, on a pooled plasma to which different concentrations of ACTH had been added. They agreed quantitatively over all the concentrations at which the different assays could be used;5? RIA did not consistently measure a concentration of $5 \mathrm{pg} / \mathrm{ml}$ whereas the CBA could measure this concentration readily. ${ }^{53}$ This correlation has been a normal finding in such static conditions. Even in normal subjects, although RIA tends to read higher than CBA, there is usually a good correlation between the results obtained by both types of assay. However, the correlation has been less good in more dynamic conditions, as pertain during insulin hypoglycaemia tests for pituitary-adrenal function ${ }^{58}$ or the thyroid releasing hormone test (TRH-test) for thyroid function ${ }^{59}$ when the hormone production is suddenly stimulated. Under these conditions, RIA apparently continues to measure biologically inactive fragments long after the biological activity of the spurt of hormone-production has decayed. Thus there may be some argument for using CBA rather than RIA in such tests.

The major discrepancies between CBA and RIA have been found in those cases where RIA has shown abnormally high values that are not consistent with the clinical state. Such conditions have included hypothalamic hypopituitarism in otherwise euthyroid patients with an exaggerated response in the TRH-test. In these it has been shown that the immunoassayable thyrotrophin had low biological activity. ${ }^{60}$ Increasingly such discrepancies are being shown to be due either to biologically inactive hormone-molecules or to the concurrent presence of some blocking agent. A particularly interesting example of the latter is the high circulating concentrations of gastrin in cases with pernicious anaemia. ${ }^{61}$ These levels were found by RIA. When tested by CBA, the responses were not parallel to those of the standard preparation of gastrin, but became parallel at dilutions of $1 / 100000$. The CBA system was then used in a modified form that demonstrated that the serum of these patients contained some material, apparently an immunoglobulin, that blocked the receptor on the parietal cells so that they could not respond to the circulating gastrin. The resulting achlorhydria caused still more gastrin to be secreted. The special interest of this study was that it indicated that the atrophic gastritis, associated with this condition, need not be caused by some dramatic cytotoxic influence: it could occur simply by a blockade of the trophic influence of the hormone that may be essential for the growth of the cells and the successful turnover of the tissue-elements.

\section{Studies on biologically-active immunoglobulins}

It seems to be rather easier to demonstrate the existence, in some diseases, of abnormal immunoglobulins, that to ascribe a biological function to them. This applies, for example, to the antibodies to DNA in systemic lupus erythematosus and to the antimicrosomal antibodies in thyroid disease: there is little evidence that either functions against living cells in life. The group of immunoglobulins that characteristically occur in Graves' disease ${ }^{62}$ obtrude their function as thyroid stimulating immunoglobulins (TSI) by the thyrotoxicosis that is evident when they are present. It has also been suggested that goitre could be a manifestation of growth-stimulating immunoglobulins. One of the advantages of the development of cytochemistry, and the CBA-system, is that such an hypothesis can now be tested, very much as the biochemical manifestations of a physiological function induced by a hormone can be the basis of a cytochemical bioassay of that hormone. Thus the physiological function is that the plasma of goitrous subjects may contain a factor inducing growth of the thyroid gland. In biochemical terms, growth requires the synthesis of DNA and this can readily be tested cytochemically. Thus by the application of the CBA-system, it has now been shown ${ }^{63}$ that there are indeed thyroid-growth stimulating immunoglobulins (TGI) in patients who have goitres, even without thyrotoxicosis. Serum from such patients stimulates the synthesis of DNA, as measured by microdensitometry of the Feulgen reaction (and confirmed by autoradiography), in segments of guinea-pig thyroid gland maintained in vitro in the presence of immunoglobulins from these patients.

\section{Conclusion}

Cytochemistry is now such a precise, quantitative form of cellular biochemistry that it allows the assay of biologically active polypeptide hormones to be made with a sensitivity about one thousand times that of radioimmunoassay. The same basic equip- 
ment and expertise can already be applied to the assay of a range of hormones, and it is likely that the list of hormones that can be assayed by this system will increase in the near future. The immediate extension of these assays has been the use of the CBA-system to demonstrate the presence of blocking immunoglobulins, as in pernicious anaemia, and of growth-stimulating immunoglobulins. Both these demonstrations have elucidated what would otherwise be mysterious pathological features: thus the CBA-system has contributed to the evaluation of pathological circulating influences.

The measurement of material circulating in the blood is the province of chemical pathology. In general, the chemical pathologist depends on the presence, in the circulation, of abnormal components liberated either from dead, or from severely unwell, cells. He has performed his tasks so well that interest is now turning to the chemical basis of dysfunctions which may not be so severe as to allow characteristic chemical entities to leak out of the dysfunctioning cells. Such chemical analyses can now be done, provided that a biopsy of the relevant tissue can be obtained; they call for a combined histopathological and chemical pathological study. An example of such dysfunctions is the chest pain often associated with mitral leaflet prolapse. By means of quantitative cytochemistry applied to myocardial biopsies, it was shown that the myocardium was indeed ischaemic even though it was not so severely disturbed as to contribute circulating material for the chemical pathologist. ${ }^{64}$

Thus the cytochemical bioassays should not be considered solely in the context of endocrinology. In principle, at least, they can be used to demonstrate the existence of, and assay, many biologically active substances that may circulate, even at low concentrations (ng-pg/ml). But they have wider implications. They show that cytochemistry, as it has now developed, can measure with some degree of precision, biochemical changes in target-cells within a complex tissue. There seems to be no reason why such cytochemistry could not be used to extend biochemical histopathology to the analysis of biochemical changes, induced by disease-processes, in target-cells within a biopsy.

\section{Appendix}

TERMS USED IN MICRODENSITOMETRY AND BIOASSAY

Chromogenic reactions: reactions involving colourless or slightly coloured reagents which produce a strongly coloured reaction product.

Chromophore: a molecule that "bears colour" -that is, a molecule that absorbs light.
Index of precision: this is a way of assessing how precise an assay can be. It is compounded of the variance between replicates $\left(\mathbf{S}_{\mathbf{y x}}\right)$ and the slope (b). For example, a particular variance could invalidate an assay which has a shallow slope for its calibration graph but might not invalidate an assay which has a steep slope. Thus the index of precision $\lambda=\left(\mathbf{S}_{\mathrm{yx}}\right) / \mathrm{b}$.

Mean integrated extinction, often referred to as "integrated extinction": in microdensitometry the absorption of each region of a cell is measured and the results are summed to give the total absorption of the measured region. For comparative studies, this amount of absorption over a known area of the specimen is converted from arbitrary units of absorption to absolute units of extinction (as used in conventional spectrophotometry). This is done by means of a calibration graph that relates the total absorption of the known area to absolute extinction. However, this value is the mean extinction of all the points measured by the scanning spot throughout the region measured. Hence it is the mean of all the extinctions of the integrated measurements made for each field by the scanning spot. Since the mean extinction of each field must be less than 1.0 (ideally $<0.7)$ the value is often multiplied by 100 to give whole numbers. Thus if the mean extinction of all the integrated points is $\mathbf{0 . 3 2}$, this is transformed into a mean integrated extinction $\times 100$ of 32 .

Slope: the slope (b) of a calibration graph is the increase in the activity measured per unit increase in dose-that is, the increase in mean integrated extinction for a tenfold increase in the concentration of hormone applied to the tissue.

Stoichiometry: a definite and known relation between the activity to be measured and the amount of reaction product produced by the reaction.

\section{References}

${ }^{1}$ Slater TF, ed. Biochemical mechanisms of liver injury. London and New York: Academic Press, 1978.

2 Chayen J, Denby EF. Biophysical technique as applied to cell biology. London: Methuen, 1968.

${ }^{3}$ Caspersson T. Uber den Chemischen Aufbau der Strukturen des Zellkernes. Skand Arch Physiol 1936;73:Supp] 8.

- Caspersson T. Methods for determination of absorption spectra of cell structures. Journal of the Royal Microscopical Society 1940;60:8-25.

${ }^{5}$ Caspersson T. Cell growth and cell function. A cytochemical study. New York: Norton, 1950.

- Chayen J. Microdensitometry. In: Slater TF, ed. Biochemical mechanisms of liver injury. London and New York: Academic Press, 1978:257-91.

7 Deeley EM. An integrating microdensitometer for biological cells. J Sci Instrum 1955;32 :263-7.

${ }^{8}$ Bitensky L. Microdensitometry. In: Trends in enzyme histochemistry and cytochemistry. London: Ciba Foundation, 1980;73:181-202.

${ }^{9}$ Chayen J, Bitensky L, Butcher RG. Practical histochemistry 
New York and London: Wiley, 1973.

${ }^{10}$ Stuart J, Simpson JS. Dehydrogenase enzyme cytochemistry of unfixed leucocytes. J Clin Pathol 1970;23: 517-21.

11 Stuart J. Quantitative enzyme cytochemistry in acute leukaemia. In: Pattison JR, Bitensky L, Chayen J, eds. Quantitative cytochemistry and its applications. London and New York: Academic Press, 1979:113-27.

12 Wickramasinghe SN. Studies on the cell cycle in human bone marrow. In: Pattison JR, Bitensky L, Chayen J, eds. Quantitative cytochemistry and its applications. London and New York: Academic Press, 1979:9-22.

${ }^{13}$ Linderstrøm-Lang K, Mogensen KR. Studies on enzymatic histochemistry, 32. C $R$ Trav Laboratory Carlsberg Series Chim 1938;23:37-42.

${ }^{14}$ Lynch R, Bitensky L, Chayen J. On the possibility of supercooling in tissues. Journal of the Royal Microscopical Society $1966 ; 85: 213-22$.

${ }^{15}$ Chayen J, Bitensky L. Multiphase chemistry of cell injury. In: Bittar EE, Bittar N, eds. The biological basis of medicine. New York: Academic Press, 1968;1:337-68.

${ }^{16}$ Tammann G. The states of aggregation (Mehl RF, trans.). New York: Van Nostrand, 1925.

${ }^{17}$ Chayen J. The cytochemical approach to hormone assay. Int Rev Cytol 1978;53:333-96.

${ }^{18}$ Chayen J. The cytochemical bioassay of polypeptide hormones. Berlin, Heidelberg and New York: Springer, 1980.

19 Altman FP, Barrnett RJ. The ultra-structural localisation of enzyme activity in unfixed tissue sections. Histochemistry $1975 ; 41: 179-83$.

${ }^{20}$ Zoller LC, Weisz J. A demonstration of regional differences in lysosome membrane permeability in the membrana granulosa of graafian follicles in cryostat sections of rat ovary: a quantitative cytochemical study. Endocrinology 1980;106:871-7.

${ }^{21}$ Butcher RG. The chemical determination of section thickness. Histochemie $1971 ; 28: 131-6$.

22 Altman FP, Chayen J. Retention of nitrogenous material in unfixed sections during incubation for histochemical demonstration of enzymes. Nature 1965;207:1205-6.

${ }^{23}$ Altman FP, Chayen J. The significance of a functioning hydrogen-transport system for the retention of 'soluble' dehydrogenases in unfixed sections. Journal of the Royal Microscopical Society 1966;85:175-80.

24 Altman FP, Butcher RG, Chayen J. The retention of cell components and structure in unfixed sections during histochemical investigations. Journal of the Royal Microscopical Society $1965 ; 84: 401$.

${ }^{25}$ Butcher RG. Tissue stabilisation during histochemical reactions: the use of collagen polypeptides. Histochemie $1971 ; 28: 231-5$.

${ }^{28}$ Henderson B, Loveridge N, Robertson WR. A quantitative study of the effects of different grades of polyvinyl alcohol on the activities of certain enzymes in unfixed tissue sections. Histochem $J$ 1978;10:453-63.

${ }^{27}$ Chayen J, Gilbert DM, Robertson WR, Bitensky L, Besser GM. A cytochemical section bioassay for thyrotrophin. Journal of Immunoassay 1980;1:1-13.

${ }^{28}$ Pattison JR, Bitensky L, Chayen J, eds. Quantitative cytochemistry and its applications. London and New York: Academic Press, 1980.

29 Chayen J, Daly JR, Loveridge N, Bitensky L. The cytochemical bioassay of hormones. Recent Prog Horm Res 1976;32:33-79.

${ }^{30}$ Lipscomb HS, Nelson DH. A sensitive biologic assay for ACTH. Endocrinology 1962;71:13-23.

${ }^{31}$ Sayers MA, Sayers G, Woodbury LA. The assay of adrenocorticotrophic hormone by the adrenal ascorbicdepletion method. Endocrinology $1948 ; 42: 379-93$.
32 Daly JR, Alaghband-Zadeh J, Loveridge N, Chayen J. The cytochemical bioassay of corticotropin (ACTH). Ann N Y Acad Sci 1977;297:242-59.

${ }^{33}$ Walsh JH, Grossman MI. Gastrin. N Engl J Med 1975;292: 1324-34.

${ }^{34}$ Besser GM, Cullen DR, Irvine WJ, Ratcliffe JG, Landon J. Immunoreactive corticotrophin levels in adrenocortical insufficiency. $\mathrm{Br}$ Med J 1971; i:374-6.

${ }^{35}$ Matsuyama H, Ruhman-Wennhold A, Johnson LR, Nelson DH. Disappearance rates of exogenous and endogenous ACTH from rat plasma measured by bioassay and radioimmunoassay. Metabolism 1972;21: 30-5.

36 Juilliard JH, Shibaski T, Ling N, Guilleman R. Highmolecular-weight immunoreactive $\beta$-endorphin in extract of human placenta is a fragment of immunoglobulin G. Science 1980;208:183-5.

37 Orth DN. Assay of ACTH. Discussion. Ann NY Acad Sci 1977;297:260-2.

38 Yalow RS. Heterogeneity of peptide hormones. Recent Prog Horm Res 1974;30:597-633.

39 Rees LH, Ratcliffe JG. Ectopic hormone production by non-endocrine tumours. Clin Endocrinol (Oxf) 1974;3: 263-99.

${ }^{40}$ Rees LH. The biosynthesis of hormones by non-endocrine tumours: a review. J Endocrinol 1975;67:143-75.

41 Bloomfield GA, Holdaway IM, Corrin B, Ratcliffe JG, Rees GM, Ellison M, Rees LH. Lung tumours and ACTH production. Clin Endocrinol (Oxf) 1977;6:95-104.

42 Rees LH. ACTH, lipotrophin and MSH in health and disease. Clin Endocrinol Metab 1977;6:137-53.

43 WHO Expert Committee on Biological Standardisation. 26th report. WHO Tech Rep Ser 1975:565.

44 Sayers G, Swallow RL, Giordano ND. An improved technique for the preparation of isolated rat adrenal cells: a sensitive, accurate, specific method for the assay of ACTH. Endocrinology $1971 ; 88: 1063-8$.

${ }^{45}$ Dufau M, Mendelson CR, Catt $\mathrm{KJ}$. A highly sensitive in vitro bioassay for luteinizing hormone and chorionic gonadotropin: testosterone production by dispersed Leydig cells. J Clin Endocrinol Metab 1974;39:610-7.

${ }^{46}$ Romani P, Robertson DM, Diczfalusy E. Biologically active luteinizing hormone (LH) in plasma. 1. Validation of the in vitro bioassay when applied to plasma of women. Acta Endocrinol (Copenh) 1976;83:454-5.

${ }^{47}$ Trowell OA. The culture of mature organs in a synthetic medium. Exp Cell Res 1959;16:118-47.

${ }^{48}$ Chayen J, Chayen R, Besser GM, Bitensky L. Quantitative cytochemistry in the detection and analysis of sensitive rapid effects of hormones. Biochem Soc Trans 1979;7: 857-60.

49 Bitensky L, Alaghband-Zadeh J, Chayen J. Studies on thyroid stimulating hormone and the long-acting thyroid stimulating hormone. Clin Endocrinol (Oxf) 1974;3:36374.

${ }^{50}$ Loraine JA, Bell ET. Hormone assays and their clinical application. Edinburgh and London: Livingstone, 1971: 14.

${ }^{51}$ Daly JR, Loveridge N, Bitensky L, Chayen J. The cytochemical bioassay of corticotrophin. Clin Endocrinol (Oxf) 1974;3:311-8.

52 Loveridge N, Bloom SR, Welbourn RB, Chayen J. Quantitative cytochemical estimation of the effect of pentagastrin $(0.005-5 \mathrm{pg} / \mathrm{ml})$ and of plasma gastrin on the guinea-pig fundus in vitro. Clin Endocrinol $(O x f)$ $1974 ; 3: 389-96$.

${ }^{53}$ Holdaway IM, Rees LH, Ratcliffe JG, Besser GM, Kramer RM. Validation of the redox cytochemical assay for corticotrophin. Clin Endocrinol (Oxf) 1974;3:329-34.

${ }^{54}$ Meakin JW, Bethune JE, Despointes RH, Nelson DH. The 
rate of disappearance of ACTH activity from the blood of humans. J Clin Endocrinol Metab 1959;19:1491-5.

${ }^{\text {B5 }}$ Petersen V, Smith BR, Hall R. A study of thyroid stimulating activity in human serum with the highly sensitive cytochemical bioassay. J Clin Endocrinol Metab 1975;41 : 199-202.

${ }^{56}$ Buckingham JC, Chayen J, Hodges JR, Robertson WR, Weisz $\mathrm{J}$. A cytochemical section assay method for the determination of luteinizing hormone. J Endocrinol 1979; $81: 160 P$.

${ }^{57}$ Rees LH, Ratcliffe JG, Besser GM, Kramer RM, Landon J, Chayen J. A comparison of the redox assay for ACTH with previous assays. Nature 1973;241:84-6.

68 Fleisher MR, Glass D, Bitensky L, Chayen J, Daly JR. Plasma corticotrophin levels during insulin-hypoglycaemia: comparison of radioimmunoassay and cytochemical bioassay. Clin Endocrinol (Oxf) 1974;3: 203-8.

"Ealey PA. Validation of the cytochemical bioassay of thyrotrophin and its application to selected clinical problems. PhD thesis, University of London, 1979.

60 Faglia G, Bitensky L, Pinchera A, et al. Thyrotropin secretion in patients with central hypothyroidism: evidence for reduced biological activity of immunoreactive thyrotropin. J Clin Endocrinol Metab 1979;48:989-98.

${ }^{61}$ Loveridge N, Bitensky L, Chayen $\mathrm{J}$, et al. Inhibition of parietal cell function by human gamma-globulin containing gastric parietal-cell antibodies. Clin Exp $\stackrel{\mathcal{S}}{\square}$ Immunol 1980;41:264-70.

${ }^{62}$ McKenzie JM, Zakarija M. LATS in Graves' disease. Recent Prog Horm Res 1977;33:29-57.

os Drexhage HA, Bottazzo GF, Bitensky L, Chayen J, Doniach D. Evidence for thyroid-growth-stimulating $\varrho$ immunoglobulins (TGI) in some goitrous thyroid क्ष diseases. Lancet 1980;ii:287-92.

${ }^{4}$ Malcolm AD, Cankovic-Darracott S, Chayen J, Jenkins $\overrightarrow{0}$ BS, Webb-Peploe MM. Biopsy evidence of left ventricular myocardial abnormality in patients with mitral- $\vec{\omega}$ leaflet prolapse and chest pain. Lancet $1979 ; \mathrm{i}: 1052-5$.

Requests for reprints to: Dr J Chayen, The Mathilda and Terence Kennedy Institute of Rheumatology, 6 Bute of Gardens, Hammersmith, London W6 7DW, England. 